\title{
Chronology of Bioactive Glass Development and Clinical Applications
}

\section{Larry L. Hench}

Department of Materials Science and Engineering, University of Florida, Gainesville, USA.

Email: larryhench@embarqmail.com

Received November $13^{\text {th }}, 2012$; revised December $15^{\text {th }}, 2012$; accepted December $25^{\text {th }}, 2012$

Copyright (c) 2013 Larry L. Hench. This is an open access article distributed under the Creative Commons Attribution License, which permits unrestricted use, distribution, and reproduction in any medium, provided the original work is properly cited.

\begin{abstract}
The key research and development steps for bioactive glass (45S5 Bioglass) are documented from the date of discovery in 1969 through FDA approvals of the first dental, ENT, maxillo-facial and orthopedic clinical products. Understanding the mechanisms and quantifying the rapid surface reactions to form a bone-bonding hydroxyl-carbonate apatite (HCA) layer on the bioactive glass in contact with living bone was a vital part of the early development of this class of biomaterials. A key later discovery was enhanced osteogenesis and in situ bone regeneration by controlled release of ionic dissolution products from the bioactive glass particulates that leads to up-regulation and activation of seven families of genes, a process called osteostimulation.
\end{abstract}

Keywords: Bioactive Glass; 45S5 Bioglass; Hydroxyl-Carbonate Apatite (HCA); Bone-Bonding; Osteogenesis; Regeneration; Genes, Dental; ENT; Maxillo-Facial; Orthopedics; Clinical; Osteostimulation

\section{Introduction}

This paper documents a field of glass research and development pioneered over the last 40 years that has greatly enhanced the length and quality of life. One of the first major developments leading to saving of life was the optical microscope. Invention of the microscope using glass spheres to focus light on objects was the seminal step towards discovering microscopic life forms of bacteria, viruses and fungi, e.g. pathogens. This discovery led to treatment and eventually elimination of many diseases that was instrumental in creating the improvements in public health and healthcare that occurred in the 19th and 20th centuries. This enormous social change can be termed a revolution in Life Preservation. A major consequence of life preservation was an expansion of the human lifespan from an average of 45 years to $80+$ years. It is projected that by 2050 there will be more than 1 billion people alive on earth aged 60 years old or older.

A second revolution in healthcare has occurred during the last 50 years, i.e. a revolution in Tissue Replacement. From the age of 30 years old onwards, all tissues progressively deteriorate. Thus, an increase in length of life is usually accompanied by a decrease in quality of life. To repair, replace and restore the function of hips, knees, eyes, ears, teeth, hearts, kidneys, etc. is now commonplace. Human "spare parts" is a huge business worth tens of billions of dollars.

The first generation of materials used for tissue replacement was selected by surgeons and materials scientists and engineers to be as biologically inert as possible, therefore they are called bio-inert materials. Corrosion resistant metals and insoluble, non-toxic polymeric materials became the standard biomaterials. However, all bio-inert materials are a compromise because of the incompatibility of the interface between the material and living tissue. Tissue breakdown and loosening over time is a common mode of failure of devices made from bio-inert materials. Stress shielding due to mis-match of elastic moduli of high strength biomaterials and bone leads to resorption of bone and long term implant failure and revision surgeries. Wear of articulating surfaces also leads to creation of wear debris and osteolysis leading to degradation of the interfacial supporting bone.

An alternative, second generation concept for tissue replacement using a special type of glass was discovered in 1969. This concept of "bioactivity" has made it possible to expand greatly the approaches taken in tissue replacement. Bioactive materials form a bond with living tissues. The objective of this paper is to document the chronology of discovery and development of bioactive glasses to become an important range of clinical materials used worldwide for tissue replacement and regenera- 
tion. The first part of this paper discusses the mechanism of bioactive bonding and in vitro and in vivo evidence generated to achieve governmental regulatory approval of clinical uses of $45 \mathrm{~S} 5$ Bioglass. The second part of the paper documents the clinical applications of bioactive glasses and glass-ceramics. Recent research has discovered that glasses with especially high levels of bioactivity can also be used to activate genes to stimulate the body to repair itself. This discovery has led to the concept of using slowly resorbable bioactive glasses as a third generation of biomaterials designed for tissue regeneration. The third part of the paper discusses the concept of genetic control of tissue regeneration and long term advantages.

\section{Discovery of Bioactive Glasses}

For millennia it was accepted that any man-made material in the body would result in a foreign body reaction and formation of non-adherent scar tissue at the interface with the material. Thus, initial emphasis on biomaterials for use in the body was on materials that were as inert as possible when exposed to a physiological environment. Prevention of corrosion of metals or degradation of polymers was the primary design objective. This first generation biomaterials approach to replacement of tissues was irreversibly altered when a special composition of soda-lime-phosphate-silicate glass was made by the author and implanted in the femurs of rats in 1969 by Dr. Ted Greenlee and colleagues at the University of Florida [1-3]. The glass composition contained $45 \% \mathrm{SiO}_{2}$, in weight \% with network modifiers of $24.5 \% \mathrm{Na}_{2} \mathrm{O}$ and $24.5 \% \mathrm{CaO}$. In addition $6 \% \mathrm{P}_{2} \mathrm{O}_{5}$ was added to the glass composition to simulate the $\mathrm{Ca} / \mathrm{P}$ constituents of hydroxyapatite (HA), the inorganic mineral phase of bone, Table 1.

The glass composition was denoted as $45 \mathrm{~S} 5$ to signify

Table 1. Composition of bioactive glasses and glass-ceramics used for medical and dental applications.

\begin{tabular}{cccc}
\hline $\begin{array}{c}\text { Composition } \\
(\text { wt } \%)\end{array}$ & $\begin{array}{c}\text { 45S5 Bioglass } \\
\text { (NovaBone) }\end{array}$ & $\begin{array}{c}\text { S53P4 } \\
\text { (AbminDent1) }\end{array}$ & $\begin{array}{c}\text { A-W Glass-ceramic } \\
\text { (Cerabone) }\end{array}$ \\
\hline $\mathrm{Na}_{2} \mathrm{O}$ & 24.5 & 23 & 0 \\
$\mathrm{CaO}$ & 24.5 & 20 & 44.7 \\
$\mathrm{CaF}_{2}$ & 0 & 0 & 0.5 \\
$\mathrm{MgO}$ & 0 & 0 & 4.6 \\
$\mathrm{P}_{2} \mathrm{O}_{5}$ & 6 & 4 & 16.2 \\
$\mathrm{SiO}_{2}$ & 45 & 53 & 34 \\
& & Glass & Apatite \\
Phases & Glass & B & Glass \\
Class of bioactivity & A & B & B \\
\hline
\end{tabular}

the weight \% of silica (S) as the network former and a 5 -fold ratio of $\mathrm{Ca} / \mathrm{P}$. The glasses did not form interfacial scar tissue isolating them from the host femoral bone, and could not be removed from their implant site [1-3]. This discovery led to the development of a new class of biomaterials, called bioactive materials, for use in implants or prostheses and repair or replacement of bones, joints and teeth. Table 2 summarizes the chronology of the development of bioactive glasses as a second generation of biomaterials. The discovery in 1969 was published as a peer reviewed paper in 1971 [1]. This seminal paper describes the composition of the glass and the evidence of bonding to bone by use of transmission electron microscopy (TEM) that reveals the bonded interface as a layer of growing bone mineral that has interdigitated with collagen fibrils generated by osteoblasts growing at the interface. In this first paper an acellular in vitro model of the glass samples in a calcium phosphate-rich solution showed by X-ray diffraction (XRD) the steps of growth of a biologically active hydroxyapatite crystal phase on the surface of the glass that mimics the XRD pattern of the HA phase in living bone. Details of the bone-bonded interface are described in a second set of papers in 1971-1972 [2,3].

\section{Compositions of Bioactive Glasses}

Bioactive materials, including bioactive glasses [1-3] and glass-ceramics [4-6], are special compositions made typically from the $\mathrm{Na}_{2} \mathrm{O}-\mathrm{CaO}-\mathrm{MgO}-\mathrm{P}_{2} \mathrm{O}_{5}-\mathrm{SiO}_{2}$ system (Table 1). All of the compositions in Table 1 form a mechanically strong bond with bone. Details are described in [7-15]. The rate of bone bonding depends upon composition of the material. Glass compositions with the fastest rates of bone bonding also bond to soft tissues [16].

Bioactive materials are used as bulk implants to replace bones or teeth, coatings to anchor orthopaedic or dental devices or in the form of powders, as bone grafts, to fill various types of bone defects. When a particulate of bioactive glass is used to fill a bone defect the rate and quantity of bone regeneration depend on the material's composition [7-15].

Compositions such as 4555 Bioglass with high rates of bioactivity produce rapid regeneration of trabecular bone with an amount, architecture and bio-mechanical quality of bone that matches that originally present in the site. The rapid regeneration of bone is due to a combination of processes called osteostimulation and osteoconduction [16-19]. Large differences in rates of in vivo bone regeneration and extent of bone repair indicate that there are two classes of bioactive materials (Table 1) [16-19].

\section{Classes of Bioactivity}

Class A bioactivity leads to both osteoconduction and 
Table 2. Chronology of science and clinical product development of $45 \mathrm{~S} 5$ bioglass.

\begin{tabular}{|c|c|}
\hline 1969 & Discovery of bone bonding to 45S5 Bioglass at University of Florida [Report to US Army Medical RD Command] \\
\hline 1971 & First peer reviewed publications of bonding of bone to bioactive glasses and glass-ceramics [1-3] \\
\hline 1972 & Bonding of Bioglass bone segments and coated femoral stems in monkeys $[9,10]$ \\
\hline 1975 & Bioglass coated alumina bone bonding to sheep hip implants (in Germany) [11] \\
\hline 1977 & Bonding of Bioglass implant in guinea pig middle ear [17] \\
\hline 1977 & Patent applications filed for Bioglass coatings on metals and alumina ceramics [17] \\
\hline 1981 & Discovery of soft connective tissue bonding to 45S5 Bioglass [16] \\
\hline 1981 & Toxicology, biocompatibility studies (20 in vitro and in vivo) to establish safety for FDA clearance of Bioglass products [16] \\
\hline 1985 & First medical product (Bioglass Ossicular Reconstruction Prosthesis) (MEP) cleared by FDA via the 510 (k) process [17,35-38] \\
\hline 1987 & Discovery of osteoproduction (osteostimulation) in use of Bioglass particulate in repair of periodontal defects $[17,39,43]$ \\
\hline 1988 & Bioglass Endosseous Ridge Maintenance Implant (ERMI) cleared by FDA via the $510(\mathrm{k})$ process $[17,31-34,40,41]$ \\
\hline 1991 & Develop sol-gel process method to make bioactive gel-glasses extending bioactive compositional range of bioactivity [45,46] \\
\hline 1993 & $\begin{array}{l}\text { Bioglass particulate for use in bone grafting to restore bone loss from periodontal disease in infrabony } \\
\text { defects (Perioglas) cleared by FDA via the } 510(\mathrm{k}) \text { process [17] }\end{array}$ \\
\hline 1995 & Perioglas obtained CE Mark in Europe [17] \\
\hline 1996 & Use of Perioglas for bone grafts in tooth extraction sites, alveolar ridge augmentation cleared by FDA via the $510(\mathrm{k})$ process $[17,39,43]$ \\
\hline 1999 & European use of $45 S 5$ particulate for orthopedic bone grafting (NovaBone) [17,33,42] \\
\hline 2000 & FDA clearance for use of NovaBone in general orthopedic bone grafting in non-load bearing sites $[17,33,42]$ \\
\hline \multicolumn{2}{|r|}{2000 Quantitative comparison of rate of trabecular bone formation in presence of Bioglass granules versus synthetic HA and A/W glass-ceramic [14 } \\
\hline 2000 & Analysis of use of $45 \mathrm{~S} 5$ Bioglass ionic dissolution products to control osteoblast cell cycles [22,25] \\
\hline 2001 & Gene expression profiling of 45S5 Bioglass ionic dissolution products to enhance osteogenesis [26,27] \\
\hline 2004 & FDA clearance of $45 \mathrm{~S} 5$ particulate for use in dentinal hypersensitivity treatment (NovaMin) $[17,44]$ \\
\hline 2005 & Development of variety of dental maintenance products (NovaMin) $[17,44]$ \\
\hline 2009 & Anniversary of 1 million doses of NovaBone bone graft product and 1 million tubes of NovaMin toothpaste \\
\hline 2011 & $\begin{array}{l}\text { Acquisition of NovaMin technology by Glaxo-Smith-Kline and world launch of Sensodyne } \\
\text { Repair and Protect toothpaste for prevention of dentinal hypersensitivity and gingivitis }\end{array}$ \\
\hline
\end{tabular}

osteostimulation as a consequence of rapid reactions on the bioactive glass surface [16-19]. The surface reactions involve dissolution of critical concentrations of soluble $\mathrm{Si}$ and $\mathrm{Ca}$ ions that give rise to both intracellular and extracellular responses at the interface of the glass with its physiological environment. The intracellular and extracellular response of osteoprogenitor cells results in rapid formation of osteoid bridges between particles, followed by mineralization to produce mature bone structures $[17,19]$. Rates of osteoproduction of various bioactive particulates have been quantified by Oonishi et al. that provide the fundamental in vivo comparisons of Class A vs. Class B bioactive materials [14].

\section{Bioactivity Reaction Stages}

New surface and interfacial analyses techniques were developed to understand the mechanisms and kinetics of bioactive reactions in vitro and in vivo [1,8,12,13,20-23]. These methods showed that there is a sequence of eleven reaction stages that occur at the surface of a Class A bioactive glass. Figure 1 indicates in the log time axis that the first five stages of surface reactions occur very rapidly and go to completion within 24 hours for the bioactive glasses with highest levels of bioactivity, e.g. 4555 Bioglass. The effect of the surface reactions is rapid release of soluble ionic species from the glass into the interfacial solution. A high surface area composed of hydrated silica and polycrystalline hydroxyl-carbonate apatite (HCA) bi-layer is formed on the glass surface within hours (Stages 1-5). The reaction layers enhance adsorption and desorption of growth factors (Stage 6) and decrease greatly the length of time macrophages are required to prepare the implant site for tissue repair (Stage 7). 


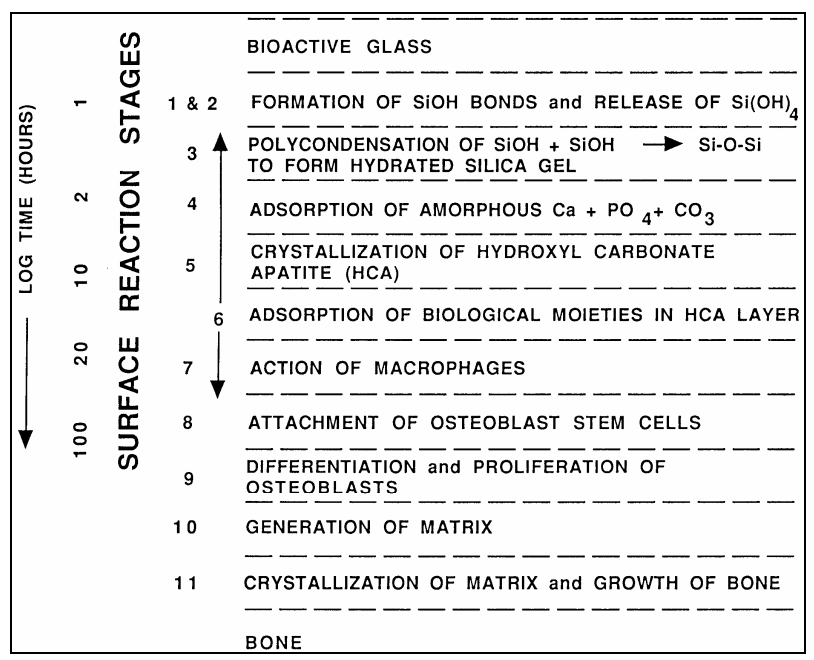

Figure 1. Sequence of interfacial reactions between bone and a class a bioactive glass or glass-ceramic.

Attachment of stem cells (Stage 8) and synchronized proliferation and differentiation of the cells, (Stage 9) rapidly occurs on the surface of Class A bioactive materials [12,15-17,24-30]. Several weeks are required for similar cellular events to occur on the surface of bio-inert and Class B bioactive materials. Differentiation of progenitor cells into a mature osteoblast phenotype does not occur on bio-inert materials and is rare on Class B bioactive materials because of the lack of ionic stimuli. In contrast, osteoprogenitor cells colonize the surface of Class A bioactive materials within 24 - 48 hours and begin production of various growth factors which stimulate cell division, mitosis, and production of extracellular matrix proteins, (Stage 10) [24-28]. Mineralization of the matrix follows soon thereafter and mature osteocytes, encased in a collagen-HCA matrix, are the final product by 6 - 12 days in vitro and in vivo (Stage 11) [12,14-16, 23-28].

\section{Cell Cycle Control and Gene Activation}

There are very few cells in the bones of older people that are capable of dividing and forming new bone. The few osteoprogenitor cells that are present must receive the correct chemical stimuli from their local environment that instruct them to enter the active segments of the cell cycle leading to cell division (mitosis) and eventually regeneration of new bone (osteogenesis). References [25], [28] and [29] summarize the sequence of cellular events that comprise a cell cycle for a single osteoblast progenitor (adult stem) cell and its division into daughter cells and differentiation into mature bone cells.

Resting cells are in the $G_{0}$ phase and unless they are stimulated to enter into active phases of the cell cycle they will not lead to bone regeneration. A new cell cycle begins after a cell has completed mitosis. A key to re- generative repair of bone is to: 1) control the population of cells that are capable of entering into active phases of the cell cycle; 2) complete the mitosis of cells with accurate replication of genes (cell proliferation); and 3) achieve cellular differentiation into a phenotype capable of synthesizing a full complement of extracellular proteins that constitute a mature osteocyte $[29,30]$.

The studies reported by Xynos et al. showed that such osteoblast cell cycle control is achieved by the controlled release of ionic dissolution products from 45S5 bioactive glass [23-28]. Osteoprogenitor cells colonize the surface of the bioactive glass; however, the concentration of soluble $\mathrm{Si}$ and $\mathrm{Ca}$ ions at the cell-solution interface is critical for controlling the cell cycle and activating a series of seven families of genes responsible for osteogenesis. Controlled rates of dissolution of the glass provide the critical concentration of the biologically active ions to the cells via the interfacial solution. The families of genes that are unregulated and/or activated are related to the relevant segments of the cell cycle, cell proliferation and cell differentiation. Details are given in [23-28] and reviewed in [29,30].

\section{Clinical Applications}

Table 2 summarizes the chronology of the science and development of clinical products from the date of the first discovery of 45S5 Bioglass in November 1969.

A listing of medical and dental products based upon 45S5 Bioglass is given in Tables 3-5. Key papers describing development of the clinical products are given in [30-43]. Details are reviewed in [17-19]. Numerous clinical citations are given in [17] for all the products listed in Tables 3-5. The year 2009 heralded the 40th anniversary of the discovery of $45 \mathrm{~S} 5$ Bioglass and the landmark sales of the one millionth dose of the bone graft product (NovaBone and Perioglas). That year also marked sales of the one millionth tube of tooth paste containing $45 \mathrm{~S} 5$ particulate (NovaMin) designed to oc-

Table 3. Orthopedics products based upon 45S5 bioglass.

\begin{tabular}{cc}
\hline & $\begin{array}{r}\text { Long bone fracture (acute and/or comminuted); } \\
\text { alone and with internal fixation } \\
\text { Trauma } \\
\text { Femoral non-union repair } \\
\text { Tibial plateau fracture }\end{array}$ \\
Arthroplasty $\quad$ Filler around implants (acetabular reconstruction) \\
Impaction grafting \\
Filling of bone after cyst/tumor removal \\
Spine fusion $\quad$ Interbody fusion (cervical, thoracolumbar, lumbar) \\
Posterolateral fusion \\
Adolescent idiopathic scoliosis
\end{tabular}


Table 4. Cranial-facial products based upon 4555 bioglass.

\begin{tabular}{cc}
\hline Cranioplasty & Facial reconstruction \\
Extraction sites \\
General oral/dental defects & Alveolar ridge augmentation \\
& Sinus elevation \\
Cystectomies \\
Periodontal repair & Osteotomies \\
\hline
\end{tabular}

Table 5. Dental-maxillofacial-ENT products based upon 45S5 bioglass.

Toothpaste and treatments for dentinal hypersensitivity

Pulp capping

Sinus obliteration

Repair of orbital floor fracture

Endosseous ridge maintenance implants

Middle ear ossicular replacements (Douek MED)

clude dentinal tubules and remineralize the surface of teeth, thereby eliminating the cause of dentinal hypersensitivity. In 2011 Glaxo-Smith-Kline acquired the NovaMin technology and has launched a superbly successful over the counter version of bioactive toothpaste called Sensodyne Repair and Protect that prevents dentinal pain sensitivity and inhibits gingivitis. It is an example of the use of bioactive materials as a preventative treatmentthe latest revolution in healthcare. This technology and method of function of the bioactive glass particulate is described in chapter 31 in [44].

\section{Bioactive Glasses in Tissue Engineering}

In 1991 it was discovered that bioactive glasses could be made using a low temperature sol-gel chemical process $[45,46]$. A much broader compositional range for bioactivity was possible with bioactive gel-glasses due to the high surface area of the final product [46]. Sol-gel processing also made it possible to produce bioactive gelglass foams with the highly controlled hierarchical porosity required for cell infiltration into large interconnected 3-D pores, a requirement for viable tissue engineered constructs [47-58]. A comprehensive review by Dr. Julian R. Jones describes development of such TE constructs, historical aspects and other recent topics in this field [58].

\section{Conclusion}

The discovery of bonding of bone to specific composi- tions of glasses led to a new, second generation of bioactive materials for tissue replacement. Understanding gene activation of human progenitor cells by controlled release of ionic dissolution products from bioactive glasses provides the basis for design of third generation biomaterials that can be used for tissue regeneration. Use of bioactive glass particulate in prevention of oral disease and damage is an example of a fourth generation of biomaterialsbioactive materials for prevention of tissue damage. Bioactive glass science and technology continues to be at the forefront of providing innovative approaches to medicine.

\section{REFERENCES}

[1] L. L. Hench, R. J. Splinter, W. C. Allen and T. K. Greenlee Jr., "Bonding Mechanisms at the Interface of Ceramic Prosthetic Materials,” Journal of Biomedical Materials Research, Vol. 2, No. 1, 1971, pp. 117-141. doi:10.1002/jbm.820050611

[2] C. A. Beckham, T. K. Greenlee Jr. and A. R. Crebo Jr., "Bone Formation at a Ceramic Implant Interface," Calcified Tissue Research, Vol. 8, No. 1, 1971, pp. 165-171. doi:10.1007/BF02010133

[3] T. K. Greenlee Jr., C. A. Beckham, A. R. Crebo and J. C. Malmborg, "Glass Ceramic Bone Implants," Journal of Biomedical Materials Research, Vol. 6, No. 3, 1972, pp. 235-244. doi:10.1002/jbm.820060312

[4] U. Gross and V. Strunz, "The Interface of Various Glasses and Glass-Ceramics with a Bony Implantation Bed,” Journal of Biomedical Materials Research, Vol. 19, No. 3, 1985, pp. 251-271. doi:10.1002/jbm.820190308

[5] T. Kokubo, S. Ito, S. Sakka and T. Yamamuro, "Formation of a High-Strength Bioactive Glass-Ceramic in the System MgO-CaO-SiO $-\mathrm{P}_{2} \mathrm{O}_{5}$," Journal of Materials Science, Vol. 21, No. 2, 1986, pp. 536-540. doi:10.1007/BF01145520

[6] T. Yamamuro, L. L. Hench and J. Wilson, "Handbook on Bioactive Ceramics: Bioactive Glasses and Glass-Ceramics,” Vol. 1. CRC Press, Boca Raton, 1990.

[7] L. L. Hench and H. A. Paschall, "Direct Chemical Bonding of Bioactive Glass-Ceramic Materials and Bone," Journal of Biomedical Materials Researc, Vol. 7, No. 4, 1973, pp. 25-42. doi:10.1002/jbm.820070304

[8] L. L. Hench and H. A. Paschall, "Histo-Chemical Responses at a Biomaterials Interface,” Journal of Biomedical Materials Researc, No. 5, 1974, pp. 49-64.

[9] G. Piotrowski, L. L. Hench, W. C. Allen and G. J. Miller, "Mechanical Studies of the Bone-Bioglass Interfacial Bond,” Journal of Biomedical Materials Researc, Vol. 9, No. 4, 1975, pp. 47-61. doi:10.1002/jbm.820090408

[10] L. L. Hench, H. A. Paschall, W. C. Allen and G. Piotrowski, "Interfacial Behavior of Ceramics Implants," National Bureau of Standards Special Publication, Vol. 415, 1975, pp. 19-35.

[11] P. Griss, D. C. Greenspan, G. Heimke, B. Krempien, R. Buchinger, L. L. Hench and G. Jentschura, "Evaluation of 
a Bioglass Coated $\mathrm{Al}_{2} \mathrm{O}_{3}$ Total Hip Prosthesis in Sheep," Journal of Biomedical Materials Research, Vol. 10, No. 4, 1976, pp. 511-518. doi:10.1002/jbm.820100406

[12] A. E. Clark, L. L. Hench and H. A. Paschall "The Influence of Surface Chemistry on Implant Interface Histology: A Theoretical Basis for Implant Materials Selection," Journal of Biomedical Materials Research, Vol. 10, No. 2, 1976, pp. 161-174. doi:10.1002/jbm.820100202

[13] J. J. Hren, P. F. Johnson, S. R. Bates and L. L. Hench, "STEM/EDX Analysis of Bone-Bioglass Interface," Electron Microscopy Society of America, 1976, pp. 290-291.

[14] H. Oonishi, L. L. Hench, J. Wilson, F. Sugihara, E. Tsuji, M. Matsuwura, S. Kin, T. Yamamoto and S. Mizokawa, "Quantitative Comparison of Bone Growth Behaviour in Granules in Bioglass ${ }^{\circledR}$, A-W Glass-Ceramic, and Hydroxyapatite,” Journal of Biomedical Materials Research, Vol. 51, No. 1, 2000, pp. 37-46.

doi:10.1002/(SICI)1097-4636(200007)51:1<37::AID-JB M6>3.0.CO;2-T

[15] L. L. Hench and A. E. Clark, “Adhesion to Bone,” In: D. F. Williams and G. D. Winter, Eds., Biocompatibility of Orthopaedic Implants, Vol. 2, Chapter 6, CRC Press, Boca Raton, 1982, pp. 85-105.

[16] J. Wilson, G. H. Pigott, F. J. Schoen and L. L. Hench, “Toxicology and Biocompatibility of Bioglass," Journal of Biomedical Materials Research, Vol. 15, No. 6, 1981, p. 805. doi:10.1002/jbm.820150605

[17] L. L. Hench, June W. Hench and D. C. Greenspan, "Bioglass: A Short History and Bibliography," Journal of the Australian Ceramic Society, Vol. 40, No. 1, 2004, pp. $1-42$.

[18] L. L. Hench, "Bioceramics: From Concept to Clinic," Journal of the American Ceramic Society, Vol. 74, No. 7, 1991, pp. 1487-1510. doi:10.1111/j.1151-2916.1991.tb07132.x

[19] L. L. Hench, "Bioceramics," Journal of the American Ceramic Society, Vol. 81, No. 7, 1998, pp. 1705-1728. doi:10.1111/j.1151-2916.1998.tb02540.x

[20] L. L. Hench, "Characterization of Glass Corrosion and Durability,” Journal of Non-Crystalline Solids, Vol. 19, 1975, pp. 27-39. doi:10.1016/0022-3093(75)90067-8

[21] A. E. Clark Jr., C. G. Pantano Jr. and L. L. Hench, "Auger Spectroscopic Analysis of Bioglass Corrosion Films,” Journal of the American Ceramic Society, Vol. 59, No. 1-2, 1976, pp. 37-39. doi:10.1111/j.1151-2916.1976.tb09382.x

[22] C. Y. Kim, A. E. Clark and L. L. Hench, "Early Stages of Calcium-Phosphate Layer Formation in Bioglass,” Journal of Non-Crystalline Solids, Vol. 113, No. 2-3, 1989, pp. 195-202. doi:10.1016/0022-3093(89)90011-2

[23] L. L. Hench and D. E. Clark, "Physical Chemistry of Glass Surfaces," Journal of Non-Crystalline Solids, Vol. 28, No. 1, 1978, pp. 83-105. doi:10.1016/0022-3093(78)90077-7

[24] I. D. Xynos, M. V. J. Hukkanen, J. J. Batten, I. D. Buttery, L. L. Hench and J. M. Polak, "Bioglass ${ }^{\circledR} 45 S 5$ Stimulates Osteoblast Turnover and Enhances Bone Formation in
Vitro: Implications and Applications for Bone Tissue Engineering," Calcified Tissue International, Vol. 67, No. 4, 2000, pp. 321-329. doi:10.1007/s002230001134

[25] L. L. Hench, J. M. Polak, I. D. Xynos and L. D. K. Buttery, "Bioactive Materials to Control Cell Cycle,” Material Research Innovations, Vol. 3, No. 6, 2000, pp. 313323. doi:10.1007/s100190000055

[26] I. D. Xynos, A. J. Edgar, L. D. Buttery, L. L. Hench and J. M. Polak. "Ionic Dissolution Products of Bioactive Glass Increase Proliferation of Human Osteoblasts and Induce Insulin-Like Growth Factor II mRNA Expression and Protein Synthesis," Biochemical and Biophysical Research Communications, Vol. 276, No. 2, 2000, pp. 461465. doi:10.1006/bbrc.2000.3503

[27] I. D. Xynos, A. J. Edgar, L. D. K. Buttery, L. L. Hench and J. M. Polak, "Gene Expression Profiling of Human Osteoblasts Following Treatment with the Ionic Dissolution Products of Bioglass ${ }^{\circledR}$ 45S5 Dissolution,” Journal of Biomedical Materials Research, Vol. 55, No. 2, 2001, pp. 151-157.

doi:10.1002/1097-4636(200105)55:2<151::AID-JBM100 1>3.0.CO;2-D

[28] L. L. Hench, I. D. Xynos, A. J. Edgar, L. D. K. Buttery, J. M. Polak, J. P. Zhong, X. Y. Liu and J. Chang, "Gene Activating Glasses,” Journal of Inorganic Materials, Vol. 17, 2002, pp. 897-909.

[29] L. L. Hench, "Glass and Genes: The 2001 W. E. S. Turner Memorial Lecture,” Glass Technology, Vol. 44, 2003, pp. 1-10.

[30] L. L. Hench, "Bioactive Glasses: Gene Activation, Chapter 4,” In: L. L. Hench, Ed., An Introduction to Bioceramcs, 2nd Edition, Imperial College Press, London, 2013, pp. 63-68.

[31] H. R. Stanley, L. L. Hench, R. Going, C. Bennett, S. J. Chellemi, C. King, N. Ingersoll, E. Ethridge and K. Kreutziger, "The Implantation of Natural Tooth Form Bioglasses in Baboons," Oral Surgery, Oral Medicine, Oral Pathology, Vol. 45, No. 5, 1976, pp. 339-356. doi:10.1016/0030-4220(76)90168-7

[32] H. R. Stanley, et al., "Implantation of Natural Tooth Form Bioglasses in Baboon,” The International Journal of Oral Implantology, Vol. 1, 1976, p. 2.

[33] M. S. Karlan, L. L. Hench, M. Madden and M. Ogino, “A Bone-Bonding Bioactive Material Implant in the Head and Neck: Bioglass,” Surgical Forum, Vol. 39, 1979, pp. 575-577.

[34] H. R. Stanley, L. L. Hench, C. G. Bennett Jr., S. J. Chellemi, C. J. King III, R. E. Going, N. J. Ingersoll, E. C. Ethridge, K. L. Kreutziger, L. Loeb and A. E. Clark, "The Implantation of Natural Tooth Form Bioglass ${ }^{\circledR}$ in Baboons-Long Term Results," The International Journal of Oral Implantology, Vol. 2, No. 2, 1981, pp. 26-36.

[35] G. E. Merwin, J. S. Atkins, J. Wilson and L. L. Hench, "Comparison of Ossicular Replacement Materials in a Mouse Ear Model," Otolaryngology. Head and Neck Surgery, Vol. 90, No. 4, 1982, pp. 461-469.

[36] J. Wilson, J. S. Atkins, G. E. Merwin and L. L. Hench. "Histopathological Evaluation of Interaction between 
Tympanic Membrane and Implant Materials,” Transactions of the Society for Biomaterials, Vol. 8, 1985, p. 195.

[37] G. Merwin, L. Rogers, J. Wilson and R. Martin, "Facial Bone Augmentation Using Bioglass ${ }^{\circledR}$ in Dogs," Archives of Otolaryngology-Head and Neck Surgery, Vol. 112, No. 3, 1986, pp. 280-284.

[38] G. E. Merwin, "Bioglass ${ }^{\circledR}$ Middle Ear Prosthesis: Preliminary Report," The Annals of Otology, Rhinology, and Laryngology, Vol. 5, No. 1, Part 1, 1986, pp. 78-82.

[39] J. Wilson, S. Low, A. Fetner and L. L. Hench, "Bioactive Materials for Periodontal Treatment: A Comparative Study,” In: A. Pizzoferrato, P. G. Marchetti, A. Ravaglioli and A. J. C. Lee, Eds., Biomaterials and Clinical Applications, Elsevier Science Publishers, Amsterdam, 1987, pp. 223-228.

[40] M. B. Hall, H. R. Stanley, C. King, F. Colaizzi, D. Spilman and L. L. Hench, "Early Clinical Trials of 45S5 Bioglass ${ }^{\circledR}$ for Endosseous Ridge Maintenance with a New Endosseous Implant Material," The Journal of Prosthetic Dentistry, Vol. 58, No. 5, 1987, pp. 607-613. doi:10.1016/0022-3913(87)90393-3

[41] H. R. Stanley, M. B. Hall, F. Colaizzi and A. E. Clark, "Residual Alveolar Ridge Maintenance with a New Endosseous Implant Material,” Journal of Prosthetic Dentistry, Vol. 58, No. 5, 1987, pp. 607-613.

[42] J. Wilson and G. E. Merwin, "Biomaterials for Facial Bone Augmentation: Comparative Studies,” Journal of Biomedical Materials Research, Vol. 22, Suppl. A2, 1988, pp. 159-177. doi:10.1002/jbm.820221308

[43] J. Wilson and S. B. Low, "Bioactive Ceramics for Periodontal Treatment: Comparative Studies in the Patus Monkey,” Journal of Applied Biomaterials, Vol. 3, No. 2, 1992, pp. 123-169. doi:10.1002/jab.770030208

[44] L. L. Hench, Ed., “An Introduction to Bioceramics," Chapters 6-12 \& 31, 2nd Edition, Imperial College Press, London, 2013.

[45] L. L. Hench and J. K. West, "The Sol-Gel Process," Chemical Reviews, Vol. 90, No. 1, 1990, pp. 33-72. doi:10.1021/cr00099a003

[46] R. Li, A. E. Clark, and L. L. Hench, “An Investigation of Bioactive Glass Powders by Sol-Gel Processing,” Journal of Applied Biomaterials, Vol. 2, No. 4, 1991, pp. 231-239. doi:10.1002/jab.770020403

[47] P. Sepulveda, J. R. Jones, L. L. Hench, "Synthesis of Sol-Gel Derived Bioactive Foams," Key Engineering Materials, Vol. 218-220, 2002, pp. 287-290.

[48] P. Sepulveda, J. R. Jones and L. L. Hench, "Bioactive Sol-Gel Foams for Tissue Repair,” Journal of Biomedical
Materials Research, Vol. 59, No. 2, 2002, pp. 340-348. doi: $10.1002 / \mathrm{jbm} .1250$

[49] P. Sepulveda, J. R. Jones, L. L. Hench, "The Effect of Temperature on the Processing and Properties of Macroporous Bioactive Glass Foams,” Key Engineering Materials, Vol. 218-220, 2002, pp. 299-302.

[50] P. Sepulveda, J. R. Jones, L. L. Hench, “In Vitro Dissolution of Melt-Derived 45S5 and Sol-Gel Derived 58S Bioactive Glasses," Journal of Biomedical Materials Research, Vol. 61, No. 2, 2002, pp. 301-311. doi:10.1002/jbm.10207

[51] P. Sepulveda, J. R. Jones and L. L. Hench, "Bioactive Materials for Tissue Engineering Scaffolds,” In: J. M. Polak, L. L. Hench and P. Kemp, Eds., Future Strategies for Tissue and Organ Replacement, Imperial College Press, London, 2002, pp. 3-24.

[52] R. F. S. Lenza, J. R. Jones, W. L. Vasconcelos and L. L. Hench, "Surface Modified 3D Scaffolds for Tissue Engineering,” Journal Materials Science, Materials in Medicine, Vol. 13, No. 9, 2002, pp. 837-842. doi:10.1023/A:1016592127407

[53] J. R. Jones, "Review of Bioactive Glass: From Hench to Hybrids,” Acta Biomateriala, Vol. 9, No. 1, 2012, pp. 4457-4486.

[54] A. G. Stamboulis, A. R. Boccaccini and L. L. Hench, "Novel Biodegradable Polymer/Bioactive Glass Composites for Tissue Engineering Applications," Advanced Engineering Materials, Vol. 4, No. 3, 2002, pp. 105-109. doi:10.1002/1527-2648(200203)4:3<105::AID-ADEM10 5>3.0.CO;2-L

[55] A. R. Boccaccini, J. A. Roether, L. L. Hench, V. Maquet and R. Jérôme, “A Composites Approach to Tissue Engineering,” Ceramic Engineering and Science Proceedings, Vol. 23, No. 4, 2002, pp. 805-816. doi:10.1002/9780470294758.ch90

[56] J. A. Roether, J. Gough, A. R. Boccaccini, V. Maquet and L. L. Hench, "Novel Bioresorbable and Bioactive Composites Based on Bioactive Glass and Polyactide Foams for Bone Tissue Engineering,” Journal of Materials Science: Materials in Medicine, Vol. 13, No. 12, 2002, pp. 1207-1214. doi:10.1023/A:1021166726914

[57] P. Sepulveda, J. R. Jones and L. L. Hench, "Bioactive Sol-Gel Foams for Tissue Repair,” Journal of Biomedical Materials Research, Vol. 59, No. 2, 2002, pp. 340-348. doi:10.1002/jbm.1250

[58] Julian R. Jones, "Review of Bioactive Glass: From Hench to Hybrids,” Acta Biomaterialia, Vol. 9, No. 1, 2013, pp. 4457-4486. 